\title{
Finnish Case of Basic Education for All - With Quality Learning Outcomes
}

\author{
Lea Kuusilehto-Awale* and Tapio Lahtero \\ University of Jyväskylä, Jyväskylä, Finland
}

\begin{abstract}
This article views behind the success of the Finnish basic education in the PISA assessments in the years 2000, 2003, 2006 and 2009. Success is here defined not only as excellent learning outcomes in reading literacy, mathematics and science, but also as a high level of educational equity and equality. The achieved outcomes are attributable to several factors, of which this article addresses especially the basic education reform of 1972-1977 and the university based teacher education leading to a master's degree. Additional attention is paid to the autonomy of the municipalities (counties), schools and teachers in building and implementing the curricula, on the respect for learning and teachers in the Finnish society, and on the role of the Finnish evaluation system in supporting the student's learning. Developing education is a long range effort continuing across election terms, as education is understood to be a cornerstone for the development of the society. This fact justifies our describing some of the Finnish national background bases for the comprehensive basic education system, where all students study in the same group.
\end{abstract}

Keywords: Education reform, teacher education, municipal autonomy, respect for learning, diagnostic and self-evaluation, classroom management

\section{Introduction}

Before World War II and after it, having lost the war, small Finland in the faraway North was one of the poorest countries in Europe well into the 1950s and the 1960s. The then basic education comprised the dual system of dividing children at about age 11 after primary school years 1-4 into either general secondary or vocational education avenues. Access to secondary education was primarily possible for children in urban areas and dependent on the socioeconomic background of the family. Access to tertiary education was even more limited. Hence, the education level of the nation was rather low (Sarjala, 1981; 2008).

Since the year 2000, Finland has been in the limelight of international educators' interest, when the first PISA (Programme for International Student Assessment) results were published. Finland was a top achiever in reading literacy, mathematics and science skills of ninth grade school leavers. The success was high in 2003 and 2006 (Organisation for 
Economic Co-operation and Development [OECD], 2001; 2004; 2007). It continued also in 2009 (OECD, 2010), as shown in Table 1.

Table 1

Finland's PISA Results in 2009 (OECD, 2010)

\begin{tabular}{llll}
\hline Finland's results & Score points & OECD countries & All participants \\
\hline Reading literacy & 536 & 2nd & 3rd \\
Mathematics literacy & 541 & 2nd & 6 th \\
Science literacy & 554 & $1 \mathrm{st}$ & 2nd \\
\hline
\end{tabular}

The Finns were taken by surprise in 2000, and have been so ever since, because in Finland teaching is not done for national or international testing. Finnish teaching has the objective of getting every student to learn as well as possible and to ignite a love for life-long learning. Education is a constitutional right for all regardless of their socio-economic status, gender, religion, ethnicity, political orientation or age. Recently, Finland has also participated successfully in the TIMMS and PIRLS evaluations.

The continuing top placements in the PISA assessments are one side of the coin. However, Finland differs from the other participants in that both the inner school variance in achievement and the variance between the schools throughout the country are very small, below the OECD average. The conclusion is that the Finnish comprehensive basic education school produces both quality learning outcomes and a high level of equity and equality (Kupiainen, Hautamäki, \& Karjalainen, 2009; Kuusilehto-Awale, 2011; Kuusilehto-Awale \& Lahtero, 2012; Simola, 2005). This paper will look not only into specific factors of mainly the post 1970s education system, but also into the wider societal context behind the success of reforms and the societal support for education and learning.

\section{Education and Teaching Policy for Learning, Not for Evaluation}

In developing the Finnish education system and implementing the Finnish education reforms, the objective has not been in outscoring the rest of the world's nations in international assessments, or scoring high on ranking lists. The Finnish pedagogical ethos is very different, focusing on equal access to education for all since the 1970s, and developing teacher capacity.

International comparative evaluations have, on one hand, emerged from the globalization and interconnectedness of the world. However, on the other hand, they are a product of neoliberal politics that has pervaded also education policy, reforms and their implementation since the late 1970s. In Finland, as well as in the other Nordic welfare countries, the adoption of neoliberal education policy has been in alignment with the global mainstream, and it has surprisingly been advanced since the 1980s regardless of the political coalition in power, 
whether headed by a Conservative, a Social Democratic or a Centre Party Prime Minister. This is clearly stated in the government programs though the word 'neoliberalism' does not exist in the Finnish governance documents (Aho, 1999; Simola, Rinne, Varjo, Pitkänen, \& Kauko, 2009). Yet, the Nordic welfare countries have adopted the neoliberal education policies to a much lesser and a softer degree than the mainstream countries, and still strongly value the egalitarian provision of education.

Interestingly, despite the fairly similar societal welfare environment of the Nordic countries and their comprehensive school systems, only Finland has exhibited excellent PISA assessment outcomes (Andersen, 2010; Wiborg, 2012). The difference was discovered as early as the 1990s when inter-Nordic education research showed the Finnish students having e.g. better reading skills (Andersen, 2010). Reasons for this difference have been estimated to come from the higher teacher qualification level, the participatory classroom management in Finland, and the fact that Finland's lowest scoring 25\% of the students achieve better than their peers in the other participating countries. It is a fact that in Finnish basic education, the early intervention methods are well developed and used as soon as a need is diagnosed, to prevent the students from losing track (e.g. Andersen, 2010; Sahlberg, 2006; Välijärvi, 2011).

Today the globally dominant discourse in education policy and implementation is the neoliberal one, which first took root in global economy. Harvey's (2005) definition of neoliberalism as "a theory of political economic practices that proposes that human wellbeing can best be advanced by liberating individual entrepreneurial freedoms within an institutional framework characterized by strong private property rights, free markets, and free trade" (p. 2) renders the major points of reference of the doctrine created by Hayek, Polanyi, and Friedman and pushed to the mainstream by PM Thatcher, President Reagan and PM Deng Xiaoping since the late 1970s, advocated and advanced strongly to date by the World Bank, the International Monetary Fund and the OECD. (Harvey, 2005; Stiglitz, 2012)

Education policy aligned to the neoliberal doctrine is implemented through decentralization, outsourcing, standardized curricula, standardized national testing, management styles applicable in the private sector, marketization and privatization. Standardized testing leads to ranking lists of schools and teachers without the socio-economic and other infrastructure factors affecting the outcomes being considered. This leads to victimizing the teachers and the school principals, closing down "underachieving" schools, and the schools tampering the evaluation results in order to pass the ranking successfully. These vicious institutional side effects exist now on record from all corners of the globe. From the viewpoint of equal access to education for all and improving learning outcomes for all, which we believe is vital for socially and economically sustainable nation building, the neoliberal policies worldwide are widening the gap between the haves and the have-nots and the reputed outcomes are attributable to a select sample of students. Moreover, that price is 
very high both socially and economically (Harvey, 2005; Simola, Rinne, \& Kivirauma, 2002; Stiglitz, 2012). Among others, Ami Volansky, an Israeli professor, describes this duality or polarization as the result of these education policies as follows:

There are two opposite strategies in the world for promoting education. One dictates a uniform curriculum, considers competition among students and educational institutions as a means of improving achievements, uses comparative exams to rank students and institutions and, therefore, labels them as well.

A second, opposite strategy can be found in Finland. Finland abolished the supervision of educational institutions and transferred state and local budgets to schools' authority. The school is responsibility for developing, improving and renewing a compulsory curriculum. Every student has their own personal program for progress, and teachers use exams as a tool for planning students' path to success. Thirty percent of students receive additional help and support. (Volansky, 2011)

Volansky's point is expressed in other words by Hargreaves, Halasz, and Pont (2007), who state that high performing Finland might be regarded as an example of positive deviance from which other nations can learn as they rethink their own reform strategies.

The Finnish teaching mindset is committed to teaching the curriculum requirements, and beyond, for the students to learn without upper limits. A standardized curriculum with standardized testing leads to the pedagogical ethos where teaching is done for the tests to be passed, i.e. mediocrity (Kuusilehto-Awale, 2011). The Finnish way must not be misunderstood as assessment and evaluation not being used. To begin with, a recent comparative survey studying classroom management differences between two differently achieving Nordic countries, Denmark and Finland, also describes how in Finland the classroom work takes place in an inclusive learning environment with a feel of togetherness, and learning aiming not only at cognitive outcomes, but also at problem solving, critical thinking, collaboration, innovation and imagination skills. The teacher is often assisted by a teaching assistant, and is a classroom manager or leader giving frequent feedback on students' work, monitoring that the work per lesson keeps aligned towards the objectives. This approach can be defined as classroom work assessment. This kind of classroom management ensures that every student may be able to have flow experiences in learning, i.e. total immersion in the joy of understanding, making findings, building new solutions and boosting self-esteem (Andersen, 2010). Further, the Finnish school pupils are tested regularly on average every three or four weeks with a diagnostic purpose: to track if sufficient learning is taking place, and whether early intervention support measures such as extra attention to the child, remedial teaching, special education methods or psychological support are needed. Early intervention has the objective of bringing the student's learning to the expected level in a timely manner. This approach has resulted in very few pupils repeating the school year. 
In addition to the above, there are also national sample tests carried out by the National Board of Education (NBE) on the higher grades of basic education to gain evidence on the equity of education provision and accomplishment corresponding to the criteria of learning outcomes for each subject issued by the NBE. The sample testing takes place in a rotating order of subjects per year. To add to this, the Finnish schools have been required to engage in mandatory self-evaluation of the yearly school work since 1994 with the introduction of the new National Curriculum Guidelines. The schools focus it on topics of their own judgment about their relevance, or on the requirements of the education provider, which most often is the autonomous municipality. The purpose of self-evaluation is to be able to engage in the continuous improvement of the school work process and performance.

\section{Respect for Learning and Teachers}

The teaching profession, learning and education have always held a high social status in Finland. Simola even posits that "teachers in comprehensive schools enjoy a higher status in Finland than in most other advanced liberal countries. What is even more rare, people at both the lower and higher ends of the social spectrum seem to appreciate and respect the teacher's work" (2005, p. 458). The roots of this respect go far back to the 1600s, when the church was in charge of schooling and enhanced literacy also by demanding that to marry before the eyes of God was subject to literacy, and the practice continued well unto the 1800s (Sarjala, 2008).

Politically, after being a part of the Swedish Empire for centuries, Finland became a Grand Duchy of Russia in 1809, enjoying a fairly liberal administration. Several reforms solidified education provision in the Finnish language. In the 1860s, primary education was made the responsibility of the local administration, the municipalities, hence diminishing the role of the church in education. The farsighted, educated Swedish speaking intelligentsia was dedicated to enhancing the provision of education for the majority of the population in their native Finnish language. Not only was the first teacher training seminary founded in Jyväskylä in 1863, but the first secondary school for boys teaching in the Finnish language was established likewise in Jyväskylä in 1863, to be followed with other similar schools in the then major towns. The objective was to educate civil servants able to perform in Finnish, one effort in the area of national awakening leading to political independence in 1917.

Other decisions taken in those days led to social innovations, which have continued being backbones of Finnish education, learning, and respect for them till today. One of them is the public library. The first ones were established in 1848. Today they are available to every citizen at no or at a minimal charge in every municipality, being multifunctional knowledge and recreation provision centers equipped with ICT facilities for any citizen to use. Further, Finland developing into a multiparty democracy, both the left and the right wing parties established associations that formed informal educational institutions educating their members into active and capable membership in the civil society and administration. From 
these late 19th century institutions developed the informal adult education colleges that are in full operation still today, offering a wide variety of liberal arts, handicrafts, arts, music, sports, ICT, etc. studies for anyone interested. Besides these institutions, there are today open universities and folk high schools. Altogether these draw yearly over 2, 2 million registrations, meaning that half of the population engages in informal studies. Hence, frequent use of libraries for reading, information and knowledge retrieval and recreation, and registering in studies of personal interest is a mental mindset in every home, and pervades all generations.

\section{Modern Long Term Educational Policy}

Contrary to the innumerable foreign visitors to Finland looking for the quick fix to improve their education systems, the Finns do not believe in a quick fix. Neither can any education system, policies or practices be transferred as such to a new context unless the question is of neo-colonialism via education. Educational reform initiatives implemented as ad hoc silver bullet enterprises have in general been doomed to failure, affecting little permanent improvement in learners' achievement (e.g. Välijärvi et al., 2007).

To achieve sustainable improvement in learning, education must be understood as a basic force behind any infrastructure of a nation, not only as an objective for a nation's economic competitiveness, as in neoliberal policy making and today's mainstream education policies. The alternative is to see the fundamental status of education as an infrastructure basis, and as a fundamental human right that shall transcend the political passions abandoning the efforts of the previous regime once power coalition changes take place. A society accepting the alternative develops to acknowledge that all political powers are the necessary stakeholders in building sufficient sustainable political consensus to implement education policies which are viable beyond power shifts in the election periods. Finland has excelled in political and social consensus building after World War II, having learnt a dire lesson also from the devastating Civil War of 1918 dividing the nation. Also, Finland has a multi-party political system, where the government can rarely be built among just a few major parties, and economic and social stability has long been ensured by the triple agreements of the government, the employers and the employee unions.

Consequently, in Finland the ministry and central office civil servants are not changed after each election, nor is a new reform implemented. This results in the education reforms extending across a period of time that guarantees the feasibility of outcomes, i.e. an interest to the investment made. This is to say that sustainably improved learning outcomes are not achievable in short time spans, as learning is a slow process due to the human nature, the teacher, the school organization, the education provider organization, and the education policy organization needing time to learn (Kuusilehto-Awale, 2012). Examples of this in practice are the policy reforms regardless of changing governments, such as the basic 
education reform of the 1970s still in force today and the curriculum reforms of 1994 and 2004 (e.g. Aho, 1999).

\section{Development Plans}

Another policy reform since the 1990s has been for the Ministry of Education to issue the five-year development plans for Education and Science, founded on the objectives set in the government programs. Also the focus in allocating state subsidies to teacher in-service training follows the guidelines issued in this development plan. To give an example of the major objectives, in the 1990s the focus was on developing the ICT infrastructure and the teachers' capacities, in the plan for 2007-2012 (Ministry of Education, 2007), the change of the environment steered the objectives from structural changes in education provision to internationalization, immigrant and multicultural education, and to connecting education to working life and enhancing entrepreneurship education.

\section{The 1970s and 1980s Education Reforms}

Finland changed from a country with agriculture and forestry dependency into an industrial one with huge rapidity in the 1950s and 1960s, and thereafter towards a knowledge based economy. The educational policy objectives for improving the nation's education level to enable the citizens to adapt to and gain employment in the rapidly changing livelihoods environment comprised the 1970s and 1980s basic education (comprehensive) school reform and raising the teacher qualification into a master's degree.

Comprehensive school reform. The PISA success of good learning outcomes combined with equity and equality in education is firmly attributed to the Comprehensive School Reform (1972-1977) of the basic education, which abolished the dual system of dividing children at about age 11 into either general secondary or vocational education tracks. Comprehensive basic education school has since been for grades 1-9, all children studying in the same mixed-ability groups with equity of access to education (Simola, 2005, p. 461). The values of the reform were equity and equal opportunity: every child regardless of the family's socio-economic background, health, ethnicity, religion or gender is entitled to having access to basic education and studying together (Sarjala, 1981).

In the first years after the reform, a streaming or tracking system was applied in foreign language and mathematics, dividing the children into three ability based levels. This led to the outcome where boys in their puberty and children from lower socio-economic backgrounds tended to remain in the lower streams, and subsequently missed access to secondary education matching their learning potential. In the 1980s, the streaming system was abolished, which means that all children face the same requirements in the same study groups. Teaching diverse learners is a challenge not only to the teacher's pedagogical skills but it also requires versatile timely measures to support the learners' varying needs. This has 
been realized through the provision of remedial teaching, special education and multiprofessional groups consisting of educators, social workers, guidance counselors, school nurses and psychologists, the exact set up depending on the local resources (KuusilehtoAwale, 2011; Kuusilehto-Awale \& Lahtero, 2012).

The implementation of the comprehensive school was regulated in a tight and detailed manner till the mid-1990s, indicating precisely the educational services and their production modes to be allocated to the citizens. Moreover, the school work was guided by detailed curricula, exact job descriptions and guidelines as well as extensive in-service training for teachers (Sarjala, 1981; Mustonen, 2003, p. 81).

From centralization to decentralization. The 1970s were a period of strong administrative centralization, when the School Board of Education governed by sending orders and the inspectors inspected the schools (Tukiainen, 1999, p. 3). Finnish societal policy began transforming at the turn of the 1970s and the 1980s towards loosening the guidance system of the central administration and increasing of the local decision making power (Lahtero, 2011, p. 21). Since the 1980s, the tendency has been to reduce the centralized guidance and to increase pedagogical guidance by objectives (Tukiainen, 1999, p. $3)$. As mentioned above, it is noteworthy that in the Finnish context this neoliberal alignment was advanced regardless of the power coalition in the government. The result of the Comprehensive School reform has been that $99.9 \%$ of students complete comprehensive school, the quality of outcomes is good both in terms of learning and low inner-school and inter-school variance, the expenditure is at an OECD average and the hours taught in school are below the OECD average. The children begin school at age seven, and almost all of them go to pre-school at age six. One must note that pre-school as well as early childhood education prioritize education and care through play, not through cognitive instruction (See e.g. Aho, Pitkänen, \& Sahlberg, 2006, p. 133). Play and to learn by playing are a child's work in Finland.

Decentralization and management by objectives and outcomes. Though governance reforms had been undertaken in the 1980s, the transformation was rather slow till the pressure at increasing the efficiency of the public economy grew in the 1990s as Finland's economy plunged into a deep depression. The depression hit Finland very hard, causing an $18 \%$ unemployment rate to last several years, remaining at circa $10 \%$ at the end of the decade. The realization in policy making was that there was no return to the old industry and working force based economy. Finland quickly decided to invest in educating the nation to a level that would enhance its adaptation to and innovation ability in the upcoming knowledge-based society. Decentralization of administration was also in Finland implemented as a means to increase the efficiency of education at a lower cost in the depression era circumstances. Decentralization and the simultaneous deregulation changed into management by objectives and outcomes (cf. Rinne, 2001). 
School-based management. Hence, decision making was decentralized to the autonomous municipalities and into the schools in them (Rinne, 2001), and instead of the former guidance by regulations and orders, the new guidance was by objectives and outcomes, as a result of which the responsibility of an individual school for dividing the resources changed considerably wider than it had been. Now also individual schools had to be able to solve how to maintain and even improve the quality of school work with the diminishing resources (Lahtero, 2011, pp. 24-25). The original objective of the basic education had been to transform the world into a better place, but in the 1990s this was replaced by the call for effectiveness and competitiveness. The efficiency of the education system seemed to be growing more important than its coverage and its quantitative service capacity (Varjo, 2007, p. 89).

University based teacher education leading to Master's degree qualification. The discussion concerning the PISA success both in the public and amongst the educators has attributed it to the committed Finnish teachers with their Master's degree qualification, and university based Finnish teacher education. The teacher education launched in the teacher training seminaries 150 years ago in 1863 was changed into universities, leading to a Master's degree (Simola, 2005).

The Teacher Education Reform was implemented during 1973-1979, and it radically changed the training of primary school teachers (teaching at the lower level of comprehensive school, from grades one to six). The responsibility for their training was removed from the teacher training colleges and small town 'teacher preparation seminaries' to the brand-new university faculties of education established as part of the reform. The training of primary school teachers was raised to the Master's degree level in 1979, which dramatically upgraded the role of educational studies in teacher training and led to the rapid adoption of education as an academic discipline (Simola, 2005, p. 461). The teaching profession is very popular in Finland. In the 2000s, among the upper secondary school graduates, teaching was the number one career choice (Simola, 2005, p. 459).

There are eleven teacher training departments in the university faculties of education in Finland, spreading throughout the country as regional access to also tertiary education has been prioritized in the national policy. The university teacher education and research work in tight collaboration with state owned teacher training schools, which educate basic and upper secondary school children, and provide practice teaching, experimenting, researching and tutoring environments to teacher students.

The account below illustrates the primary and subject teacher (grade six to grade 12) education guidelines at the University of Jyväskylä (Lindell, 2011; University of Jyväskylä, 2011). To add to these, the faculty educates early childhood, special education and sign language teachers. 
Primary teacher education. The Master's degree qualification in primary teacher education comprises 300 ECTS credit points. One ECTS credit equals 27 hours of full time work. The core contents of the curriculum comprise teachers' pedagogical studies including practice teaching, education as the major subject with research methods, school subject studies for primary school teachers, and minor subject studies including languages and ICT studies. As minor subjects, the option is from school subject studies and pedagogical studies. The allocation of ECTS per each content area is illustrated in Table 2.

Table 2

Allocation of ECTS per Content Area in Primary Teacher Education

\begin{tabular}{|c|c|c|c|}
\hline \multicolumn{4}{|c|}{ Primary Teacher Education (300 ECTS) } \\
\hline $1 \mathrm{ECTS}=27 \mathrm{hrs}$ full time work & $\begin{array}{l}\text { Bachelor's Degree } \\
(180)\end{array}$ & $\begin{array}{l}\text { Master's Degree } \\
\text { (120) }\end{array}$ & $\begin{array}{l}300 \\
\text { ECTS }\end{array}$ \\
\hline Teacher's pedagogical studies & 25 & 35 & 60 \\
\hline including teaching practice & 12 & 16 & 28 \\
\hline $\begin{array}{l}\text { Studies in education including } \\
\text { research methods }\end{array}$ & $\begin{array}{l}35 \\
\text { (including BA thesis) }\end{array}$ & $\begin{array}{l}45 \\
\text { (including MA thesis) }\end{array}$ & 80 \\
\hline $\begin{array}{l}\text { School subject studies for primary } \\
\text { school teachers }\end{array}$ & 60 & & 60 \\
\hline Minor subject studies and & 25 & $0-35$ & $\max .60$ \\
\hline language studies incl. ICT & 35 & $5-40$ & $\max .75$ \\
\hline
\end{tabular}

Primary teacher practice teaching. Practice teaching is conducted through four successive modules and realized both in the teacher training schools, and in the field schools. The practice begins with observing class dynamics and the work of the experienced training school lecturers, continues to first planning parts of lessons, then whole lessons, and teaching them, and finishes with focusing on teachers' responsibilities and professional ethics. The practice teaching is monitored by the peer teacher students, the lecturer of the teacher training school, and to a smaller scale the university didactics lecturer. After the teaching, the work is reflected by the observers present, focusing on the interaction, cognitive skills, versatility of methods, empowering the pupils, enhancing an investigative approach and reflection, communicating and evaluating different points of view, time management, and alternative choices to those made now.

There are four practice teaching modules in practice, which are as follows. Module 1 is about observation and giving six brief teaching sessions. The objective is to gain a view into the teacher's work, interaction in classroom and pupils as learners. Module 2 practices planning and implementing teaching and the assessment of outcomes. The teacher student teaches 26 lessons. In module 3, the teacher student plans, implements and assesses extensive study modules, makes appropriate pedagogical choices, decides how to guide and support the different learning processes of diverse learners, and chooses the appropriate assessment methods. Module 4 immerses the teacher student into the regulations, responsibilities and 
legislation of the teaching profession, parent-school and school-community cooperation, multi- and inter-professional interaction and professional ethics. The practice teaching covers 26 ECTS.

Subject teacher education. Like primary teacher education, the subject teacher education comprises 300 ECTS of studies. The allocation of ECTS credits per different content areas is illustrated in Table 3 below.

Table 3

Allocation of ECTS per Content Area in Subject Teacher Education

\begin{tabular}{|c|c|c|c|}
\hline \multicolumn{4}{|c|}{ Subject Education (300 ECTS) } \\
\hline $1 \mathrm{ECTS}=27 \mathrm{hrs}$ full time work & Bachelor's Degree (180) & $\begin{array}{l}\text { Master's Degree } \\
(120)\end{array}$ & $\begin{array}{l}300 \\
\text { ECTS }\end{array}$ \\
\hline Major subject studies & 60 & $60-90$ & $120-$ \\
\hline Research methods & (including BA thesis) & (including MA thesis) & 150 \\
\hline Teacher's pedagogical studies & $25-30$ & $30-35$ & 60 \\
\hline including practice teaching & 5 & 15 & \\
\hline $\begin{array}{l}\text { Co-subjects' } \\
\text { academic studies }\end{array}$ & $25-60$ & $0-30$ & $25-90$ \\
\hline $\begin{array}{l}\text { Language and communication } \\
\text { studies, incl. ICT }\end{array}$ & $35-40$ & $0-30$ & $35-70$ \\
\hline
\end{tabular}

The content areas consist of the major subject (to be taught in school) studies including research methods, teachers' pedagogical studies with teaching practice, co-subjects (minor subjects to be taught in school) academic studies, language and communication studies including ICT studies. The precondition for the teacher's pedagogical studies is the Master's degree in the teaching subject(s), major and minor(s). The teacher student does 25 ECTS of basic studies and 35 ECTS of advanced studies in education, including 20 ECTS of practice teaching.

Subject teacher practice teaching. As in the primary teacher education, the practice comprises four modules. Module 1 contains mentored orientating practice to school, teacher's work and classroom interaction, reflecting on the teacher students' own learning experiences on teaching. Each student does three teaching sessions. Module 2 is mentored basic practice. The students observe the pupils as individual learners and group members, the learning environments and working methods, and study the aims and contents of the curriculum, and teach fourteen sessions. Module 3 is mentored advanced practice of the investigative approach: the students plan a teaching experiment based on theoretical starting points and teach it during the course. They plan, implement and assess in the 12 sessions they teach. Module 4 is adapted mentored practice. The students study the culture of a field school, and the school as a learning organization. They plan activities, allocate resources and share the 
responsibilities in a work community, with a view to lifelong professional development, and teach six sessions.

The feedback from the practice teaching is parallel to that of the primary teacher training practice: through joint sessions with peers, teacher training or field school lecturer(s) and to a smaller extent, the university didactics lecturer. In sum, Finnish teacher education focuses on studies in education and the pedagogical studies, and combining theory with practice. Subject teachers' major is the subject to be taught in school, and pedagogical studies are their minor subjects of 60 ECTS credits.

Both the class teachers and the subject teachers are responsible for developing pedagogy and methodology in their schools, and the employer provides the minimum of three mandatory further education days per school year. The Finnish teachers are autonomous in the classroom, having the freedom to experiment innovations and to choose the methods they find the most appropriate for any group of students they work with.

\section{Reforms of the 1990s and the 2000s}

Decentralization brought the responsibility for the curriculum reform to the local level. The new National Board of Education (NBE) created through the merger of the Central Agency for the General Education and that for the Vocational Education, has since been responsible for publishing the National Curriculum Guidelines, the first of which was given in 1994. Based on this framework, with its core of mandatory studies for all students combined with local optional studies, the municipalities and individual schools received the right and the responsibility to create their own curricula. The objective was to guarantee them as wide a freedom as possible to produce curricula and through school based management also the structures to implement the curricula to meet the local needs, resources and conditions. The curriculum can be said to have expressed the local decision makers' will in education policy as part of national education policy (Opetushallitus, 1994, p. 15). Basically, a school is fairly self-governing, having wide decision making power on the implementation of the curriculum and the operational practices, and also full responsibility.

After a few years, however, it was found out that the school-based curricula did not quite deliver in the expected manner. Inter-school differences began to emerge both in regards to teaching contents and achievement of objectives. Neither was the mandatory self-evaluation system yet implemented systematically throughout the country (Rajanen, 2000). In the late 1990s, the renewal of the concept of learning, the rapid increase of access to technology, the development of knowledge society with the polarization following it increased the challenges faced by curricula and their implementation (Juusenaho 2004, p. 56). Consequently, a new National Curriculum Framework was launched in 2004. Despite an increase in guidance by norms from the NBE, the responsibility for preparing the curriculum and developing its 
quality remains with the municipalities responsible for the provision of education. The next curriculum reform is to be implemented in 2016.

Basically, the curriculum model is the so called encyclopaedic one, relying on a wide range of subjects comprising not only mother tongue and foreign language(s), humanities and natural sciences, and mathematics, but also physical education, arts, handicrafts and home economics, aiming at providing the student with a broad basis of general knowledge, a variety of skills and enhancing the student's holistic development. The Finnish basic education curriculum since its inception in the 1860s has not emphasized only cognitive skills, but arts and crafts, as well as moral education, and combining theory with practice in teaching. To mention a curiosity, Finland was the first country in the world to make handicrafts a compulsory school subject. This ethos belongs to the legacy of the founder of Finnish teacher education and primary school curriculum, Mr Uno Cygnaeus, a firm believer also in an egalitarian education to strengthen the morals and work ethic, the spirit of enterprise and the national consciousness (Sarjala, 1981; Tervoja, 2011).

\section{Trust}

Finland is a country with good governance and low corruption (Transparency International, 2011). Its entire population is highly educated, and the education level of women is today higher than that of men. The majority of the teachers hold a master's degree qualification (Statistics Finland, 2012). The conclusion is that in any local entity, whether a school or a municipal civil servant body, the sum total of human, social and intellectual capital is high, a precondition for successful decision making and curriculum implementation in a decentralized administrative system. It must be noted that at the local political decision making level, the availability of the aforementioned capital is a far more diversified phenomenon with municipalities of citizens having a very low education level, especially in the rural areas. For basic education outcomes to be excellent in the latter circumstances, the responsibility lies with the committed, highly qualified teachers, who indeed deliver (Sandholm, 2008).

The Finnish decentralized education system functions on the basis of trust. The role of the autonomous municipalities is to implement the educational services to their citizens, with the resources provided by the state and the municipality itself. The municipal level directors trust their principals and teachers, and the Ministry of Education and Culture and the NBE trust the local implementation of education policy to know the needs and capacities of the learners and how to care for them flexibly in a timely manner. The principal together with the teachers and parents is trusted to know how to provide the best possible education to the learners, and the parents trust the school. These societal factors are among the core features of the Finnish society (Aho, Pitkänen, \& Sahlberg, 2006, pp. 132-133). However, there are sounds of concern in regard to the uneven availability of human, intellectual and social resource in 
many an autonomous municipality for the democratic political decision making to provide educational (and other) services on an even, comparable quality basis (Kuusilehto-Awale, 2008). It was as early as in the mid 1990s that the former Director General of the NBE asked whether an entire service provision can keep functioning with equal quality, based only on trust (Hirvi, 1996).

To analyze the factors attributing to a society and an education system functioning on trust to this degree is challenging. At least they comprise a tradition of political democracy since 1917 and strong civil rights guaranteed in the constitution. Finland is a welfare society, where governance decisions are made in consensus, and a civil society, whose citizens are educated, empowered and used to influencing their decision makers and demanding transparent quality delivery of services. The underlying shared values are respect for hard work, honesty and perseverance, and the equal dignity and worth of every human being, which characterize the Finnish major religious heritage, the Lutheranism. Hence, the basic assumption is that everyone delivers and one can trust it till proved otherwise. In the context of school, the teachers are the backbone of dependable delivery: since the beginning of times they have been trusted to do so, and today especially due to their master's degree qualification. The abolition of the inspectorate system in the late 1980s added to the trust in the schools, education providers and the teachers, and was an important factor towards diminishing the atmosphere of fear and intimidation in the education system. The concept of internal motivation is likely to be a key factor in explaining the phenomenon of trust.

\section{Conclusion}

In conclusion, Finland has not adopted heavy neoliberal policies such as marketization and standardization of education: competition, studying only core subjects, standardized curricula and testing, control and test-based accountability as methods of education reform. Instead, the Finns have relied on collaboration, studying an encyclopaedic curriculum, early intervention support systems, individualization, school autonomy, and trust and responsibility. (Kuusilehto-Awale \& Lahtero, 2012; Sahlberg, 2011)

We Finns trust that our teachers know what is good for our children. They teach in an atmosphere devoid of fear in regard to external testing or inspections. The same goes for the children: They study in a learning environment free of fear thanks to their teacher's autonomy in building a conducive learning environment free of fear but rich in support. The teachers have the capacity to realize this due to their education combining theory and practice and involving versatile pedagogical skills training, as well as their genuine commitment to teaching for the students to learn, not for tests. The teachers are respected by both the parents and the society at large, and young high school graduates aspire to be teachers. The financial expenditure on national testing is low, as there is no research based evidence on the evaluation business improving learning in the classroom (e.g. Elmore, 2005; Ravitch, 2010). Instead, we allocate the resources to the teaching in the classroom and to the teachers. 
The Finnish society is characterized by good governance and little corruption, and our economic and political development has maintained a stable environment for education to thrive. Our political decision makers have long refrained from implementing ad hoc education reforms at power shifts from one coalition to the other in times of democratic elections. Education is understood to require permanence to work in peace, so that the focus stays on developing teaching and learning.

The basic education reform was implemented geographically stage by stage to cover the whole of Finland by 1977. Simultaneously as the result of the teacher education reform of the 1970s, the qualification for basic education teachers in years 1-9 was raised to a master's degree. The objective of basic education was to offer all children equal opportunities to nineyear basic education. It is the Finnish teachers who have committed themselves to the responsibility for accomplishing this objective. The skills acquired from the extensive pedagogical studies of the teacher education curriculum certainly play an important role in achieving the quality outcomes.

\section{References}

Aho, E. (1999). Koulutuspolitiikka markkinoiden puristuksessa [Education policy in the pressure of the market forces]. In Koulun ja kirjan maailma Jukka Sarjalan juhlakirja [The world of the school and the book Festschrift to Jukka Sarjala], pp. 29-47. Helsinki: Kustannusosakeyhtiö Ajatus.

Aho, E., Pitkänen, K., \& Sahlberg, P. (2006). Policy development and reform principles of basic and secondary education in Finland since 1968. Working paper series: Education 2. Washington, DC: World Bank.

Andersen, F. O. (2010). Danish and Finnish PISA results in a comparative, qualitative perspective: How can the stable and distinct differences between the Danish and the Finnish PISA results be explained? Educational Assessment and Evaluation, 22, 159-175. Hargreaves, A., Halász, G., \& Pont, B. (2007). School leadership for systemic improvement in Finland: A case study report for the OECD activity improving school leadership. Paris: OECD.

Harvey, D. (2005). A brief history of neoliberalism. Oxford: Oxford University Press. Hirvi, V. (1996). Koulutuksen rytminvaihdos, 1990-luvun koulutuspolitiikka

Suomessa.Toim.EsaPirnes [Change of rhythm in education, the 1990s education policy in Finland]. Helsinki: Otava.

Juusenaho, R. (2004). Peruskoulun rehtoreiden johtamisen eroja - sukupuolinen näkökulma [Leadership differences of basic education school principals]. Jyväskylä: Jyväskylä Studies in Education, Psychology and Social Research, 249.

Kupiainen, S., Hautamäki, J., \& Karjalainen, T. (2009). The Finnish education system and Pisa. Finland: Ministry of Education Publications, 46. 
Kuusilehto-Awale, L. (2011). Learning centered approach in education: The Finnish way. Conference presentation to Mofet Institute, Israel on Dec. 25, 2011. Retrieved from http://www.mofet.macam.ac.il/iun; http://www.youtube.com/Lea Kuusilehto.

Kuusilehto-Awale, L. (2012). El ethos del aprendizaje: el caso de Finlandia [Ethos of learning: Case Finland]. Educacíon. Revista del Centro Editorial y Comunicaciones de la Facultad de Educacíon. Tercera Época Ano 2, N. 3, julio de 2012. Lima, Perú: Universidad de San Marcos, 25-52.

Kuusilehto-Awale, L., \& Lahtero, T. (2012). Combining equity and quality in achieving excellent outcomes in education for all - Case Finland. Comparative Education Review 2012-2013, 34, 7-12.

Lahtero, T. (2011). Yhtenäiskoulun johtamiskulttuuri - symbolis-tulkinnallinen näkökulma [Leadership culture of comprehensive school - a symbolic-interpretative view]. Jyväskylä: Jyväskylä Studies in Education, Psychology and Social Research, 405. Lindell, A. (2011). Teacher education in Finland. Presentation at a Teacher Training Workshop, March 21-25, 2011, organized by the VPDF (Vietnam Peace and Development Foundation) in Hanoi, Vietnam.

Ministry of Education. (2007). Koulutus ja tutkimus 2007-2012 kehittämissuunnitelma. [Education and research 2007-2012 development plan]. Opetusministeriön julkaisuja [Ministry of Education Publications], Finland, 2008:9.

Mustonen, K. (2003). Mihin rehtoria tarvitaan? Rehtorin tehtävät ja niiden toteutuminen Pohjois-Savon yleissivistävissä kouluissa [What is the principal needed for? The principal's duties and their implementation].Oulu: Oulun yliopisto, Kasvatustieteiden tiedekunta, Kajaanin opettajankoulutusyksikkö.

OECD. (2001). Knowledge and skills for life: First results from PISA 2000. Paris.

OECD. (2004). Learning for tomorrow's world: First results from PISA 2003. Paris.

OECD. (2007). Education at a glance: OECD indicators 2007. Paris.

OECD. (2010). Education at a glance: OECD indicators 2010. Paris.

Opetushallitus. (1994). Peruskoulun opetussuunnitelman perusteet [National basic education guidelines]. Helsinki: Painatuskeskus.

Rajanen, J. (2000). Selvitys koulutuksen paikallisen arvioinnin tilasta [Survey on the status of the local evaluation of education]. Helsinki: Opetushallitus.

Ravitch, D. (2010). The death and life of the great American school system How testing and choice are undermining education. New York: Basic Books.

Rinne, R. (2001). Koulutuspolitiikan käänne ja nuorten syrjäytyminen [Turn of education policy and dropout of youths]. In A. Jauhiainen, R. Rinne, \& J. Tähtinen (Eds.), Koulutuspolitiikka Suomessa ja ylikansalliset mallit [Education policy in Finland and crossnational models] (pp. 91-137). Turku: Suomen kasvatustieteellinen seura.

Sahlberg, P. (2006). Education reform for raising economic competitiveness. Journal of Educational Change, 7(4), 259-287. 
Sahlberg, P. (2011). Finnish lessons: What can the world learn from educational change in Finland? New York: Teachers College Press.

Sandholm, L. (2008). Leading change in the education sector of a rural municipality 1996-

2008. Paper presented at the 5th International Symposium of Educational Reform (ISER), Lexington, Kentucky.

Sarjala, J. (1981). Suomalainen koulutuspolitiikka [Finnish education policy]. Juva: WSOY. Sarjala, J. (2008). On the history of Finnish education and its lead principles [Lecture note]. Jyväskylä: University of Jyväskylä, Institute of Educational Leadership.

Simola, H. (2005). The Finnish miracle of PISA: Historical and sociological remarks on teaching and teacher education. Comparative Education, 41(4), 455-470.

Simola, H., Rinne, R., \& Kivirauma, J. (2002). Abdication of the education state or just shifting responsibilities? The appearance of a new system of reason in constructing educational governance and social exclusion/inclusion in Finland. Scandinavian Journal of Educational Research, 46(3), 247-263.

Simola, H., Rinne, R., Varjo, J., Pitkänen, H., \& Kauko, J. (2009, March). Quality assurance and evaluation (QAE) in Finnish compulsory schooling: A national model or just unintended effects of radical decentralization? Journal of Education Policy, 24(2), 163178.

Statistics Finland. (2012). Retrieved from www.statisticsfinland.fi

Stiglitz, J. E. (2012). The price of inequality: The avoidable causes and invisible costs of inequality. US: W.W.Norton \& Company.

Tervoja, P. (2011, Spring). The teacher makes the school. Jyväskylä Human Technology City. Retrieved from http://jyvaskyla.netpaper.fi/256

Transparency International. (2011). Retrieved from http://www.transparency.org/cpi2011/results/

Tukiainen, K. (1999). Peruskoulun rehtorin toimintaprofiili [Action profile of a basic education school principal]. Helsinki: Helsingin yliopiston opettajankoulutuslaitos.

University of Jyväskylä. (2011). Teacher education curriculum. Retrieved from https://www.jyu.fi/edu/laitokset/okl/en/curriculum/curriculum\%20pdf

Välijärvi, J. (2011). What PISA 2009 tells us [Lecture note]. Jyväskylä: University of Jyväskylä, Institute of Educational Leadership.

Välijärvi, J., Kupari, P., Linnakylä, P., Reinikainen, P., Sulkunen, S., Törnroos, J., \& Arffman, I. (2007). The Finnish success in PISA - and some reasons behind it 2. Jyväskylä: Institute for Educational Research.

Varjo, J. (2007). Kilpailukykyvaltion koululainsäädännön rakentuminen. Suomen eduskunta ja 1990-luvun koulutuspolitttinen käänne [Formation of the school legislation of the competition state. The Parliament of Finland and the 1990s education policy change]. Helsinki: Yliopistopaino. 
Volansky, A. (June 9, 2011). Finland's education riddle. Haaretz News. Retrieved from http://www.haaretz.com/print-edition/opinion/finland-s-education-riddle-1.366702 Wiborg, S. (2012). Neoliberalism and universal state education: The cases of Denmark, Norway and Sweden 1980-2011. Comparative Education, 1-17. 